\title{
DETERMINASI KARAKTERISTIK KOMITE AUDIT DALAM MEMPREDIKSI KONDISI FINANCIAL DISTRESS STUDI EMPIRIS PERUSAHAAN SEKTOR JASA YANG TERDAFTAR DI BEI TAHUN 2010-2012
}

\begin{abstract}
Financial distress is a condition where a company cannot meet or has difficulty paying off its financial obligations to its creditors. In financial case, corporate governance parties who had an effect on financial distress is the audit committee. This study investigates the impact audit committee characteristic on financial distress. The audit committee characteristics that use in this study are size of audit committee, independence of audit committee, frequency of audit commitee meeting, competence of audit committee, female audit committee, and audit committee nationality, this study use two control variable is sales growth and KAP reputation. The data being used is from annual report serices company which is listed in BEI in 2010-2012 period. Data collecting method which used in this research is metod purposive sampling. Based on the method purposive sampling, research sample total is 80 companies. Data analysis using logistic regression with SPSS 17. The result show that independence of audit committee, frequency of audit commitee meeting, female audit committee, and audit committee nationality has negative affect with financial distress. Size of audit committee and competence of audit committeem has not negative affect with financial distress.
\end{abstract}

Keywords : audit committee, corporate governance, gender, nationality, financial distress

\section{PENDAHULUAN}

Dalam era globalisasi, banyak perusahaan go public yang mempublikasikan laporan keuangan untuk memenuhi kebutuhan pihak eksternal baik investor ataupun kreditor. Hal ini dilakukan sebagai respon dari keunggulan bersaing (competitive adventage) dalam pasar modal internasional. Informasi laporan keuangan menunjukan kondisi keuangan perusahaan yang sering dijadikan acuan investor ataupun kreditor untuk mengambil keputusan dalam berinvestasi pada perusahaan.

Suatu perusahaan akan lebih mudah mendapatkan dana investasi jika kondisi keuangan perusahaan tersebut dinyatakan sehat atau tidak mengalami kondisi financial distress. Menurut Platt (2002) dalam Atmini dan Wuryana (2005), financial distress adalah kondisi penurunan perusahaan dalam keuangan, sebelum perusahaan mengalami kebangkrutan ataupun dilikuidasi. Indikator kondisi ini diantaranya penundaan pengiriman, kualitas produk menurun, dan penundaan pembayaran tagihan bank.

Analisis terhadap faktor-faktor yang dapat mempengaruhi kondisi financial distress perusahaan memungkinkan perusahaan dapat memprediksi terjadinya kondisi financial distress di masa mendatang, dengan meningkatkan faktor yang berpengaruh negative terhadap kondisi financial distress dan berkebalikannya. Good Corporate Governance memiliki pengaruh besar dalam kinerja keuangan perusahaan. Semakin perusahaan memiliki tata kelola perusahaan yang baik (Good Corporate Governance) maka kinerja 
keuangan perusahaan akan baik pula. Menurut Lizal (2002) dalam Elyanto (2013), corporate governance model merupakan salah satu penyebab terjadinya kesulitan keuangan dalam perusahaan.

Dalam penerapan good corporate governance, komite audit merupakan salah satu bagian dari mekanisme tata kelola perusahaan yang sangat penting dalam melakukan pengendalian internal (Pembayun, 2012). Tugas yang dilakukan komite audit adalah melalukan pengawasan dengan memeriksa laporan keuangan yang akan diterbitkan kepada pihak eksternal, memeriksa kebijakan akuntansi untuk menjamin terpenuhinya kepatuhan hukum, aturan dan standar akuntansi yang berlaku, memeriksa laporan grup internal audit dan grup manajemen risiko, dan melakukan pengawasan independen atas pelaksanaan corporate governance sesuai dengan ketentuan FCGI (2002).

Kinerja komite audit yang baik dan efektive dapat diukur dengan karakteristik komite audit yang terdiri dari ukuran komite audit, komite audit independen, pertemuan komite audit dan kompetensi komite audit (Pembayun dan Januarti, 2012). Dan ditambahkan dalam penelitian Rustiarini (2012) karakteristik komite audit berupa gender anggota dan kebangsaan anggota komite audit dapat mempengaruhi kualitas audit.

Penelitian yang dilakukan Rieka Sartika HS Alimudin (2012) menunjukkan bahwa ukuran komite audit dan kompetensi komite audit tidak berpengaruh signifikan terhadap kondisi financial distress sedangkan komposisi independensi komite audit dan frekuensi pertemuan komite audit berpengaruh negatif signifikan terhadap kondisi financial distress. Agatha Galuh Pembayun (2012) menyatakan bahwa ukuran komite audit dan kompetensi komite audit berpengaruh negative terhadap kondisi financial distress sedangkan komite audit independen dan pertemuan komite audit tidak berpengaruh signifikan terhadap kondisi financial distress.

Penelitian yang dilakukan Martinia Eny Kristanti (2012) menunjukkan bahwa jumlah komite audit, jumlah komisaris independen dan keahlian keuangan anggota komite audit tidak berpengaruh signifikan terhadap kondisi financial distress sedangkan frekuensi rapat komite audit berpengaruh negatif signifikan terhadap kondisi financial distress. Tifani Vota Anggarini (2010) menyatakan bahwa ukuran komite audit, independen komite audit, dan frekuensi pertemuan komite audit tidak berpengaruh signifikan terhadap kondisi financial distress sedangkan kompetensi komite audit berpengaruh negative terhadap kondisi financial distress. Hasil yang kontradiksi sering menimbulkan kebimbangan baik untuk pihak manajemen ataupun pihak yang berkepentingan dengan perusahaan, sehingga memotivasi penelitian ini untuk mencari kebenaran atas banyaknya gap research yang terjadi dan memberikan keyakinan pada salah satu hasil penelitian terdahulu.

Penelitian ini merupakan replikasi dari penelitian Agatha Galuh Pembayun dan Indira Januarti (2012) yang meneliti tentang "Pengaruh Karakteristik Komite Audit Terhadap Financial Distress". Perbedaan penelitian ini dengan penelitian yang dilakukan Pembayun (2012) adalah penambahan variabel independen berupa gender wanita anggota komite audit dan kebangsaan asing anggota komite audit, sedangkan variabel kontrol mengganti variabel size dengan sales growth. Tahun penelitian ini berbeda dengan penelitian terdahulu, jika di penelitian Pembayun menggunakan sampel tahun 2007-2010, maka penelitian ini menggunakan sampel tahun $2010-2012$.

Penambahan variabel independen berupa gender wanita komite audit dikarenakan adanya perbedaan 
sifat antara laki-laki dan wanita dalam bekerja sehingga akan mempengaruhi hasil pekerjaan. Yang umumnya seorang wanita yang memiliki sifat hati-hati, teliti, sabar, dan selalu menghindari risko, hal ini akan bermanfaat terutama dalam hal keuangan yang berhubungan dengan komite audit. Sedangkan penambahan variabel independen berupa kebangsaan asing komite audit dikarenakan adanya perbedaan sistem pendidikan dan perkembangan di setiap negara menjadikan sumber daya manusia negara maju menjadi lebih unggul dibanding sumber daya manusia negara berkembang. Sehingga memperkerjakan pegawai dari negara maju dapat memberikan nilai tambah untuk perusahaan karena keunggulan dan pengalaman mereka.

Berdasarkan uraian diatas, maka penelitian ini dilakukan untuk menjawab pertanyaan berikut ini : Apakah karakteristik komite audit berupa ukuran komite audit, independensi komite audit, frekuensi pertemuan komite audit, kompetensi komite audit, gender wanita komite audit dan kebangsaan asing komite audit berpengaruh negative terhadap kondisi financial distress?

Sesuai dengan permasalahan yang diajukan dalam penelitian ini, maka tujuan penelitian adalah untuk mengetahui faktor-faktor yang mempengaruhi kondisi financial distress khususnya untuk menjelaskan : Pengaruh karakteristik komite audit berupa ukuran komite audit, independensi komite audit, frekuensi pertemuan komite audit, kompetensi komite audit, gender wanita komite audit dan kebangsaan asing komite audit terhadap kondisi financial distress.

\section{KAJIAN PUSTAKA DAN PENGEMBANGAN HIPOTESIS}

\section{Teori Keagenan}

Teori keagenan membahas hubungan antara pihak tertentu (principal) dan pihak lainnya (agent). Umumnya dalam suatu perusahaan pemegang saham atau pemilik perusahaan menjadi principal dengan tugas menyediakan fasilitas dan dana untuk operasi perusahaan, sedangkan manajemen sebagai agent memiliki kewajiban mengelola perusahaan untuk meningkatkan kemakmuran atau laba pemilik perusahaan (Elyanto, 2013). Dalam penerapannya, seorang agent lebih memiliki informasi yang luas tentang perusahaan dibanding principal, karena agent memiliki wewenang yang diberikan principal padanya untuk menjalankan perusahaan. Untuk mencegah terjadinya masalah dalam hubungan keagenan, maka penerapan good corporate governance sangat berperan penting dalam pengawasan yang efektif dan independen (Fama dan Jensen, 1983 dalam Elyanto, 2013).

\section{Financial Distress}

Menurut Platt (2002) dalam Atmini dan Wuryana (2005), financial distress adalah kondisi penurunan perusahaan dalam keuangan, sebelum perusahaan mengalami kebangkrutan ataupun dilikuidasi. Indikator kondisi ini diantaranya penundaan pengiriman, kualitas produk menurun, dan penundaan pembayaran tagihan bank. Mengetahui kondisi financial distress lebih dini dan melakukan perbaikan dapat menghindari terjadinya kebangkrutan ataupun likuidasi. Financial distress terjadi karena ketidakmampuan perusahaan dalam menjaga kestabilan kinerja keuangan sehingga dalam tahun berjalan mengalami kerugiaan operasional atau insolvency (Rayendra, 2007 dalam Andre, 2013). Financial distress dapat terlihat dalam perusahaan 
yang mengalami laba bersih operasi selama setahun lebih menunjukan angka negative, penurunan kondisi keuangan atau tidak melakukan pembayaran deviden (Amilia dan Kristijadi, 2003).

\section{Pengembangan Hipotesis}

\section{Pengaruh Ukuran Komite Audit Terhadap Financial Distress}

Di Indonesia sudah ditentukan standard yang umum untuk menentukan jumlah anggota komite audit yang efektif sesuai dengan FCGI 2002 dan KNKG 2006 yaitu berkisar tiga - lima orang. Luasnya ukuran komite audit menyebabkan pertukaran pengetahuan dan informasi yang semakin luas antar anggota yang berbeda pendidikan, pengalaman, dan budaya (Tao dan Hutchinson, 2011 dalam Pembayun, 2012) sehingga dapat membantu kinerja komite audit dalam menyelasaikan masalah dengan hasil optimal. Ukuran komite audit yang lebih dari satu mempermudah segmentasi tugas komite audit sehingga setiap anggota dapat menjalankan tugasnya lebih fokus dan optimal. Dalam penelitian terdahulu seperti penelitian yang dilakukan oleh Pembayun dan Januarti (2012), bahwa ukuran komite audit berperan dalam meminimalkan kondisi financial distress. Dari penjelasan diatas, maka hipotesis yang dapat dirumuskan adalah :

$\mathbf{H 1}=\quad$ Ukuran komite audit memiliki pengaruh negative signifikan terhadap kondisi financial distress.

\section{Pengaruh Independensi Komite Audit Terhadap Financial Distress}

Berdasarkan KEP-305/BEJ/07-2004, perusahaan yang melakukan listed di BEJ harus memiliki komisaris independen sekurang-kurangnya 30\% dari jajaran anggota dewan komisaris. Rekomendasi dari komite audit yang independen turut berkontribusi di dalam meningkatkan perfoma perusahaan dengan rencana strategi dalam bidang keuangan perusahaan (Elyanto, 2013). Dalam penelitian terdahulu seperti penelitian yang dilakukan oleh Alimudin (2012) dan Ariesta (2013) menyatakan bahwa independensi komite audit berperan dalam meminimalkan kondisi financial distress. Dari penjelasan diatas, maka hipotesis yang dapat dirumuskan adalah :

$\mathbf{H 2}=$ Independensi komite audit memiliki pengaruh negative signifikan terhadap kondisi financial distress.

\section{Pengaruh Pertemuan Komite Audit Terhadap Financial Distress}

Di dalam rapat, setiap anggota komite audit dengan latar belakang pendidikan dan pengalaman yang berbeda-beda dapat memberikan kotribusi terbaik dalam menyelesaikan permasalahan yang dihadapi komite audit. Menurut McMullen dan Raghunanda (1996) dalam Elyanto (2013) menyatakan bahwa pertemuan komite audit yang rutin dilaksanakan akan membantu komite audit dalam proses pemeriksaan hal-hal yang berkaitan dengan masalah akuntansi dan system pengendalian internal perusahaan. Dalam FCGI (2002), komite audit biasanya perlu untuk mengadakan rapat sebanyak minimal tiga - empat kali dalam satu tahun perusahaan agar dapat menjalankan kewajiban dan tanggung jawabnya dalam pelaporan hasil audit atas keuangan perusahaan. Dalam penelitian terdahulu seperti penelitian yang dilakukan oleh Kristanti dan Syafruddin (2012), Wulandari (2011), Elyanto (2013), Alimudin (2012), dan Nuresa (2013) menyatakan bahwa frekuensi pertemuan rapat komite audit berperan dalam meminimalkan kondisi financial distress. Dari penjelasan, 
dirumuskan hipotesis sebagai berikut :

H3 = Pertemuan komite audit berpengaruh negative signifikan terhadap kondisi financial distress.

\section{Pengaruh Kompetensi Komite Audit Terhadap Financial Distress}

DalamFCGI(2002), komiteauditharusmemilikiminimal satuoranganggotayang mempunyaipengetahuan dan pengalaman yang memadai tentang keuangan dan akuntansi guna melaksanakan peran pengendalian dan pemantauan yang efektif dalam perusahaan. Komite audit yang memilki image atapun reputasi yang baik dalam keahlian akuntansi dan keuangan para anggotanya akan mendapatkan kepercayaan dari manajemen ataupun pihak eksternal dalam menjalankan tugasnya (Pembayun, 2012). Dalam penelitian terdahulu seperti penelitian yang dilakukan oleh Pembayun dan Januarti (2012), Anggarini (2010), Elyanto (2013), dan Nuresa (2013) menyatakan bahwa kompetensi komite audit berperan dalam meminimalkan kondisi financial distress. Dari penjelasan diatas, maka hipotesis yang dapat dirumuskan adalah:

$\mathbf{H 4}=\quad$ Kompetensi komite audit berpengaruh negative signifikan terhadap kondisi financial distress.

\section{Pengaruh Gender Wanita Komite Audit terhadap Financial Distress}

Komite audit harus berjalan dengan transparan, displin, dan akuntanbilitas yang tinggi. Sifat-sifat inilah yang lebih dominan pada kaum wanita dibandingkan kaum laki-laki. Kaum wanita memiliki sikap hatihati yang sering menyelamatkan perusahaan dari resiko ( risk averse) yang tinggi dalam keuangan karena penyeimbangan dan tingkat risk talking yang baik (Rustiarini, 2012). Menurut Ernst dan Yuang (2009) dalam Sihite (2012) menyatakan bahwa keberagaman gender di dalam suatu komite audit dapat meningkatkan kinerja komite audit dibandingkan yang hanya ada kelompok homogeny saja. Dalam penelitian yang dilakukan oleh Rustiarini (2011) dan Carter et.al. (2003) yang menyatakan perusahaan yang memiliki dua orang atau lebih wanita dalam dewan memiliki nilai perusahaan yang lebih tinggi daripada jumlah wanita yang kurang dari dua orang dan memiliki pengaruh terhadap kualitas audit. Dari penjelasan, dapat dirumuskan hipotesis sebagai berikut :

H5 : Gender wanita komite audit berpengaruh negative terhadap kondisi financial distress.

\section{Pengaruh Kebangsaan Komite Audit terhadap Financial Distress}

Di dalam menghadapi competitive adventage di dalam pasar modal, memiliki anggota yang berkebangsaan asing merupakan suatu keuntungan untuk perusahaan (Oxelheim dan Randoy, 2003 dalam Rustiarini, 2011). Setiap negara memiliki kualitas pendidikan yang berbeda, yang menjadikan sumber daya manusia setiap negara berbeda pula. Memiliki anggota dengan kebangsaan asing terutama yang berasal dari negara maju dapat meningkatkan pengetahuan atapun pengalaman bisnis secara professional selain dapat menciptakan jaringan internasional perdagangan (Oxelheim dan Randoy, 2003 dalam Rustiarini, 2011). Begitu pula dalam komite audit, adanya anggota komite audit yang berkebangsaan asing dapat meningkatkan kualitas kinerja komite audit di dalam menyelesaikan masalah dan pengawasan terhadap pengelolaan perusahaan. Dalam penelitian yang dilakukan oleh Rustiarini (2011) dan Ararat et.al. (2010) menyatakan bahwa keberadaan 
dewan direksi asing berpengaruh signifikan terhadap nilai perusahaan dan kaulitas audit. Dari penjelasan, dapat dirumuskan hipotesis sebagai berikut :

H6 : Kebangsaan asing komite audit berpengaruh negative terhadap kondisi financial distress.

\section{METODE PENELITIAN}

\section{Populasi dan Sampel}

Populasi dalam penelitian ini adalah annual report dari perusahaan sektor jasa yang listing di Bursa Efek Indonesia (BEI) dari tahun 2010-2012. Pemilihan sampel dalam penelitian ditentukan secara purposive sampling. Sampel perusahaan adalah perusahaan yang mengalami kesulitan keuangan (financial distress) dan perusahaan yang sehat keuangannya (non financial distress). Kriteria sampel sebagai berikut :

1. Perusahaan public sektor jasa yang listed di BEI dari tahun 2010-2012 dan yang mengalami financial distress pernah mengalami Interest Coverage Ratio (ICR) bernilai kurang dari 1 dalam jangka waktu 3 tahun.

2. Perusahaan sektor jasa memiliki nilai Interest Expense atau tidak bernilai 0 .

3. Perusahaan sektor jasa menyajikan laporan keuangan dalam mata uang rupiah.

\section{Teknik Analisis Data}

\section{Statistik Deskriptif}

Statistik diskriptif merupakan alat statistik yang berfungsi mendeskripsikan atau memberi gambaran terhadap objek yang diteliti melalui data sampel atau populasi sebagaimana adanya, yang dilihat dari mean, median, deviasi standar, nilai minimum, dan nilai maksimum.

\section{Pengujian Kelayakan Model (Goodnees of Fit)}

Pengujian kelayakan model adalah pengujian yang diperluhkan untuk memastikan tidak adanya kelemahan atas kesimpulan dari model yang diperoleh. terdiri:

1. Uji Hosmer and Lameshow

2. Uji Chi Square

3. Uji Cox and Snell'R Square dan Nagelkerke's R Square

4. Uji Klasifikasi $2 \times 2$

\section{Metode Regresi Rogistik}

Metode analisis untuk mengetahui variabel independen yang mempengaruhi secara signifikan terhadap kondisi financial distress pada perusahaan sektor jasa yaitu ukuran komite audit, independensi komite audit, pertemuan komite audit, kompetensi komite audit, gender wanita komite audit, kebangsaan asing komite audit, reputasi KAP dan sales growth adalah dengan menggunakan persamaan regresi logiatik, karena variabel dependen merupakan hubungan antara dua kategori atau binary. Hasil dari analisis regresi adalah berupa koefisien untuk masing-masing variabel independen. Persamaan regresi logistik dalam penelitian ini adalah 
sebagai berikut:

\section{Pengujian Hipotesis}

Secara statistik, ketepatan fungsi regresi sampel dalam menaksir nilai aktual dapat diukur dengan nilai signifikan.

\section{HASIL DAN PEMBAHASAN}

\section{Deskriptif Objek Penelitian}

Objek perusahaan yang digunakan dalam penelitian ini adalah perusahaan sektor jasa go public yang terdaftar di Bursa Efek Indonesia (BEI). Periode penelitian yang diambil adalah tahun 2010-2012, selama periode penelitian total perusahaan sektor jasa yang terdaftar sebanyak 669 emiten. Sampel dipilih dengan menggunakan purposive sampling. Dari waktu pengamatan 3 tahun diperoleh total data yang berjumlah 80 emiten.

Berikut ini adalah statistik deskriptif (mean, maksimum, minimum, dan standar deviasi) dari variabel yang dijadikan penelitian, yaitu ACSIZE, ACINDP, ACMEET, ACCOMP, ACGEND, ACNAT, REPKAP, SALGROW, dan DISTRESS. Ukuran komite audit (ACSIZE) yang dimiliki oleh financially distressed firms dengan rata-rata 3,08 sedangkan non financially distressed firms dengan rata-rata 3,30. Proporsi komite audit independen (ACINDP) yang dimiliki oleh financially distressed firms dengan rata-rata 90\% sedangkan non financially distressed firms dengan rata-rata 96\%. Frekuensi pertemuan rapat komite audit (ACMEET) yang dimiliki oleh financially distressed firms dengan rata-rata 4,95 sedangkan non financially distressed firms dengan rata-rata 7,65. Proporsi kompetensi komite audit (ACCOMP) yang dimiliki oleh financially distressed firms dengan rata-rata $60 \%$ sedangkan non financially distressed firms dengan rata-rata $85 \%$. Proporsi gender wanita pada komite audit (ACGEND) yang dimiliki oleh financially distressed firms dengan rata-rata 0,12 sedangkan non financially distressed firms dengan rata-rata 0,55. Proporsi kebangsaan asing pada komite audit (ACNAT) yang dimiliki oleh financially distressed firms dengan rata-rata 0,02 sedangkan non financially distressed firms dengan ratarata 0,35. Reputasi Kantor Akuntan Publik (REPKAP) yang dimiliki oleh financially distressed firms dengan ratarata 0,30 sedangkan non financially distressed firms dengan rata-rata 0,82. Tingkat pertumbuhan penjualan atau sales growth (SALGROW) yang dimiliki oleh financially distressed firms dengan rata-rata 0,02 sedangkan non financially distressed firms dengan rata-rata 0,25. Berdasarkan hasil statistik deskriptif, keseluruhan variabel dalam financially distressed firms memiliki nilai rata-rata lebih kecil dibanding non financially distressed firms.

\section{Pengujian Kelayakan Model}

\section{Uji Hosmer and Lameshow}

Berdasarkan hasil uji hosmer and lameshow's test di atas, maka dapat disimpulkan bahwa model mampu memprediksi nilai observasinya atau dapat dikatakan model dapat diterima karena cocok dengan data observasinya, hal ini karena nilai Chi-square sebesar 1,026 dengan signifikan 0,998 lebih kecil dari tingkat $\mathbf{a =}$ 0,050 . 


\section{Uji Chi Square}

Berdasarkan hasil uji chi square di atas, maka dapat disimpulkan bahwa cukup besar kemungkinan adanya hubungan antara variabel bebas dengan variabel terikatnya, hal ini karena nilai -2 log likelihood blok number 0 sebesar 110,904 mengalami penurunan yang sangat jauh pada -2 log likelihood blok number 1 sebesar 26,789. Penurunan yang terjadi sebesar (110,904-26,789) 84,115.

\section{Uji Cox and Snell's R Square dan Nagelkerke's R Square}

Berdasarkan hasil uji Cox and Snell's R Square \& Nagelkerke's R Square di atas, maka dapat disimpulkan bahwa variabel dependen dapat dijelaskan oleh variabel independen sebesar $86,7 \%$ dan sisanya $13,3 \%$ dijelaskan variabel lain di luar model. Jadi sebagian besar kondisi financial distress dipengaruhi oleh karakteristik komite audit.

\section{Uji Klasifikasi $2 \times 2$}

Berdasarkan hasil uji klasifikasi $2 \times 2$ di atas, maka dapat disimpulkan bahwa dari 40 sampel yang memiliki keuangan yang sehat (non financial distress), 37 perusahaan atau 92,5\% secara tepat dapat diprediksikan oleh model regresi logistik ini, dan 3 perusahaan tidak tepat diprediksi oleh model. Sedangkan dari 40 sampel yang memiliki keuangan yang tidak sehat (financial distress), 38 perusahaan atau 93,8\% secara tepat dapat diprediksi oleh model regresi logistik ini, dan 2 perusahaan tidak tepat diprediksi oleh model. Secara keseluruhan berarti bahwa $37+38=75$ sampel dari 80 sampel atau 93, 8\% sampel yang dapat diprediksi dengan tepat oleh model regresi logistik ini.

Model Persamaan Regresi Logistik

$$
\begin{aligned}
\operatorname{Ln}(p / 1-p) & =\text { DISTRESS }=\beta 0+\beta 1 . A C S I Z E+\beta 2 \cdot A C I N D P+\beta 3 \cdot A C M E E T+\beta 4 . A C C O M P+\beta 5 \cdot A C G E N D \\
& +\beta 6 . A C N A T+\beta 7 \cdot \text { REP-KAP }+\beta 6 . S A L G R O W+\varepsilon
\end{aligned}
$$

\section{Pengujian Hipotesis}

Pengujian koefisien regresi parsial untuk mengetahui apakah variabel independen secara individual mempengaruhi variabel dependen.

\section{Pengaruh Ukuran Komite Audit Terhadap Financial Distress}

Pengujian regresi logistik menunjukan bahwa menolak hipotesis pertama $(\mathrm{H} 1)$, sehingga variabel ukuran komite audit (ACSIZE) tidak berpengaruh terhadap kemampuan perusahaan yang berada dalam kondisi kesulitan keuangan (financial distress). Hal ini dapat terlihat dari uji hipotesis yang menunjukan nilai signifikan ACSIZE sebesar 0,592 lebih besar dibandingkan dengan taraf signifikansi 5\% (0,05). Terlihat pula pada nilai standard deviasi sebesar 0,45 yang mempunyai jarak jauh dengan nilai rata-rata sebesar 3,19. Hal ini menyebabkan hasil uji penelitian menjadi tidak signifikan.

Hal ini bertentangan dengan teori yang dikemukakan oleh Tao dan Hutchinson (2011) dalam Pembayun 
(2012) yang mengemukakan bahwa semakin luas ukuran komite audit menyebabkan adanya pertukaran pengetahuan dan informasi yang semakin luas antar anggota komite audit sehingga membantu kinerja komite audit dalam menyelesaikan masalah dengan hasil optimal. Komite audit yang belum secara maksimal dalam melaksanakan fungsinya tidak akan memberikan efek terhadap peningkatan kinerja keuangan walaupun memiliki jumlah anggota komite audit yang besar, sehingga tidak meminimalkan kondisi financial distress. Dan penelitian ini mendukung penelitian yang dilakukan oleh Anggarini (2010), Kristanti (2012), Elyanto (2013) dan Nuresa (2013) yang membuktikan bahwa ukuran komite audit tidak berpengaruh negative terhadap financial distress.

\section{Pengaruh Independensi Komite Audit Terhadap Financial Distress}

Hasil pengujian regresi logistik menunjukan bahwa menerima hipotesis kedua $(\mathrm{H} 2)$ sehingga variabel komite audit independen (ACINDP) berpengaruh negative terhadap kemampuan perusahaan yang berada dalam kondisi kesulitan keuangan (financial distress). Hal ini dapat terlihat dari uji hipotesis yang menunjukan nilai signifikan ACINDP sebesar 0,017 lebih kecil dibandingkan dengan taraf signifikansi 5\% $(0,05)$. Terlihat pula pada nilai rata-rata tingkat independensi komite audit pada financially distressed firms sebesar 0,90 yang lebih kecil dibandingkan rata-rata independensi komite audit pada non financially distressed firms sebesar 0,96. Hal ini menyebabkan hasil uji penelitian menjadi signifikan.

Dari hasil penelitian ini dapat disimpulkan bahwa komite audit independen yang dimiliki perusahaan berpengaruh terhadap efektivitas kinerja komite audit dalam menghindari kemungkinan kondisi financial distress pada perusahaan. Hal ini didukung dengan teori yang dikemukakan oleh Elyanto (2013) yang mengemukakan bahwa rekomendasi dari komite audit yang independen dalam laporan komite audit berkontribusi dalam meningkatkan perfoma perusahaan dalam rencana strategi dalam bidang keuangan perusahaan. Dan penelitian ini mendukung penelitian yang dilakukan oleh Ariesta (2012) yang membuktikan bahwa komite audit independen berpengaruh negative terhadap financial distress.

\section{Pengaruh Pertemuan Komite Audit Terhadap Financial Distress}

Hasil pengujian regresi logistik menunjukan bahwa menerima hipotesis ketiga $(\mathrm{H} 3)$ sehingga variabel frekuensi pertemuan komite audit (ACMEET) berpengaruh negative terhadap kemampuan perusahaan yang berada dalam kondisi kesulitan keuangan (financial distress). Hal ini dapat terlihat dari uji hipotesis yang menunjukan nilai signifikan ACMEET sebesar 0,010 lebih kecil dibandingkan dengan taraf signifikansi 5\% $(0,05)$. Terlihat pula pada nilai rata-rata tingkat frekuensi pertemuan komite audit pada financially distressed firms sebesar 4,95 yang lebih kecil dibandingkan rata-rata frekuensi pertemuan komite audit pada non financially distressed firms sebesar 7,65. Hal ini menyebabkan hasil uji penelitian menjadi signifikan.

Hal ini sependapat dengan teori yang dikemukakan oleh McMullen dan Raghunanda (1996) dalam Elyanto (2013) yang mengemukakan bahwa pertemuan komite audit yang rutin dilaksanakan akan membantu komite audit dalam proses pemeriksaan hal-hal yang berkaitan dengan masalah akuntansi dan system pengendalian internal perusahaan. Dan penelitian ini mendukung penelitian yang dilakukan oleh Kristanti (2012), Elyanto 
(2013), dan Nuresa (2013) yang membuktikan bahwa frekuensi pertemuan komite audit berpengaruh negative terhadap financial distress.

\section{Pengaruh Kompetensi Komite Audit Terhadap Financial Distress}

Hasil pengujian regresi logistik menunjukan bahwa menolak hipotesis keempat (H4) sehingga variabel kompetensi komite audit (ACCOMP) tidak berpengaruh terhadap kemampuan perusahaan yang berada dalam kondisi kesulitan keuangan (financial distress). Hal ini dapat terlihat dari uji hipotesis yang menunjukan nilai signifikan ACCOMP sebesar 0,306 lebih besar dibandingkan dengan taraf signifikansi 5\% (0,05).

Dalam ketetapan FCGI (2002) mengemukakan bahwa komite audit harus memiliki minimal satu orang anggota yang mempunyai pengetahuan dan pengalaman yang memadai tentang keuangan dan akuntansi guna melaksanakan peran pengendalian dan pemantauan yang efektif dalam perusahaan. Hal inilah yang menjadikam perusahaan menjadikan kompetensi komite audit sebagai mandatory atas peraturan pemerintah yang berlaku. Komite audit dalam perusahaan seperti ini sering kurang bisa menempatkan anggota komite audit berkompetensi sesuai fungsinya secara optimal. Sering kali perusahaan juga kurang jelas dalam mengidentifikasi financial litency (kemampuan keuangan) pada anggota komite audit, karena perbedaan definisi dari tiap perusahaan. Dalam suatu kompetensi komite audit yang baik tidak hanya memiliki pengalaman / pendidikan akuntansi dan keuangan, namun juga harus memahami ilmu hukum, peraturan pasar modal, proses bisnis dan industri perusahaan terkait guna menunjang dalam fungsi tugas komite audit perusahaan (Alijoyo, 2003).

\section{Pengaruh Gender Komite Audit Terhadap Financial Distress}

Hasil pengujian regresi logistik menunjukan bahwa menerima hipotesis kelima $(\mathrm{H} 5)$ sehingga variabel gender wanita pada komite audit (ACGEND) berpengaruh negative terhadap kemampuan perusahaan yang berada dalam kondisi kesulitan keuangan (financial distress). Hal ini dapat terlihat dari uji hipotesis yang menunjukan nilai signifikan ACGEND sebesar 0,021 lebih kecil dibandingkan dengan taraf signifikansi 5\% $(0,05)$. Terlihat pula pada nilai rata-rata tingkat gender komite audit pada financially distressed firms sebesar 0,12 yang lebih kecil dibandingkan rata-rata gender komite audit pada non financially distressed firms sebesar 0,55 . Hal ini menyebabkan hasil uji penelitian menjadi signifikan.

Dari hasil penelitian ini dapat disimpulkan bahwa gender komite audit mampu menunjang efektivitas kinerja dari komite audit pada perusahaan. Hal ini mendukung penelitian yang dilakukan oleh Rustiarini (2011) dan Sihite (2012) yang membuktikan bahwa keberadaan gender wanita pada komite audit berpengaruh terhadap kinerja komite audit yang akan berpengaruh negative terhadap kondisi financial distress.

\section{Pengaruh Kebangsaan Komite Audit Terhadap Financial Distress}

Hasil pengujian regresi logistik menunjukan bahwa menerima hipotesis keenam (H6) sehingga variabel kebangsaan asing pada komite audit (ACNAT) berpengaruh negative terhadap kemampuan perusahaan yang berada dalam kondisi kesulitan keuangan (financial distress). Hal ini dapat terlihat dari uji hipotesis 
yang menunjukan nilai signifikan ACNAT sebesar 0,007 lebih kecil dibandingkan dengan taraf signifikansi 5\% $(0,05)$. Terlihat pula pada nilai rata-rata tingkat kebangsaan asing komite audit pada financially distressed firms yang memiliki rata-rata kebangsaan asing komite audit sebesar 0,02 yang lebih kecil dibandingkan rata-rata kebangsaan komite audit pada non financially distressed firms sebesar 0,35.

Dari hasil penelitian ini dapat disimpulkan bahwa kebangsaan asing komite audit mampu menunjang efektivitas kinerja dari komite audit pada perusahaan. Hal ini mendukung penelitian yang dilakukan oleh Rustiarini (2011) dan Ararat et.al. (2010) yang membuktikan bahwa kebangsaan asing dalam dewan ataupun komite audit berpengaruh terhadap nilai perusahaan dan kualitas audit dari komite audit yang berpengaruh negative pula terhadap financial distress.

\section{Pengaruh Variabel Kontrol Reputasi KAP dan Sales Growth Terhadap Financial Distress}

Untuk variabel kontrol reputasi KAP (REPKAP) diperoleh nilai beta korelasi sebesar -3,147 dengan signifikansi sebesar 0,036. Nilai signifikansi yang berada di bawah 0,05 menunjukan adanya pengaruh yang signifikan dari variabel REPKAP terhadap financial distress. Hal ini dikarenakan perusahaan yang diaudit oleh auditor eksternal KAP yang termasuk dalam BIG4 hasil auditnya memiliki nilai yang real sehingga memberikan nilai kinerja keuangan yang baik pula.

Untuk variabel kontrol sales growth (SALGROW) diperoleh nilai beta korelasi sebesar -2,253 dengan signifikansi sebesar 0,255. Nilai signifikansi yang berada di atas 0,05 menunjukan tidak adanya pengaruh yang signifikan dari variabel SALGROW terhadap financial distress. Hal ini dikarenakan jika penjualan mengalami perubahan yang ikuti searah dengan biayanya, maka laba operasional tidak akan menunjukan penurunan kondisi financial distress.

\section{Uji Simultan}

Berdasarkan hasil uji omnimus tests of model coefficients di atas, maka dapat disimpulkan bahwa secar keseluruhan dari 8 predikator secara simultan dapat mempengaruhi kondisi financial distress, hal ini karena nilai signifikan sebesar 0,000 lebih kecil daripada nilai $\alpha=0,050$.

\section{Kesimpulan}

Berdasarkan hasil penelitian yang telah dilakukan, dapat disimpulkan bahwa variabel independendi komite audit, pertemuan komite audit, gender wanita komite audit dan kebangsaan asing komite audit berpengaruh negative signifikan terhadap kondisi financial distress. Sedangkan variabel ukuran komite audit dan kompetensi komite audit terbukti tidak memiliki pengaruh signifikan terhadap kondisi financial distress.

\section{Keterbatasan dan Saran}

Keterbatasan dalam penelitian ini yang masih perlu menjadi bahan revisi penelitian selanjutnya adalah masih banyaknya informasi mengenai komite audit pada laporan tahunan perusahaan tidak lengkap sehingga jumlah sampel semakin sedikit. Sedangkan saran yang dapat diterapkan dalam penelitian selanjutnya adalah 
mengukur karakteristik komite audit lainnya, seperti komitmen waktu komite audit, karena anggota komite audit yang pada tahun penelitian tidak bekerja lebih dari tiga perusahaan memiliki konsentrasi kerja lebih baik dibandingkan anggota komite audit yang bekerja pada lebih dari tiga perusahaan, sehingga akan berpengaruh pada kinerja keuangan dalam memprediksi kondisi financial distress. Dan diharapkan penelitian selanjutkan dapat mengkategorikan kebangsaan asing komite audit dari negara maju atau berkembang agar dapat mengetahui perbedaan pengaruh dua kategori tersebut. Karena tenaga kerja asing yang berasal dari negara maju akan lebih unggul dalam kinerjanya dibanding tenaga kerja asing dari negara berkembang, hal ini didukung pendidikan, pengalaman dan teknologi yang berkembang pada negara tersebut.

Saran untuk OJK dan manajemen perusahaan, dari hasil penelitian ini sebagian besar kondisi financial distress dipengaruhi oleh karakteristik komite audit dengan arah negative. Sehingga perlu peningkatan independensi, frekuensi pertemuan rapat, gender wanita dan kebangsaan asing komite audit dalam upaya meminimalkan kondisi financial distress.

\section{DAFTAR PUSTAKA}

Aji, Aditya Bayuputranto. 2012. Analisis Pengaruh Karakteristik Komite Audit terhadap Kualitas Laba dan Manajemen Laba di BEI. Skripsi. Semarang: Program Sarjana. Universitas Diponegoro.

Alijoyo, F. Antonius. 2003. Keberadaan \& Peran Komite Audit Dalam Rangka Implementasi GCG. Seminar Nasional GCG FKSPI BUMN/BUMD. Surabaya.

Alimudin, Rieka Sartika HS. 2012. Pengaruh Karakteristik Komite Audit terhadap Financial Distress pada Perusahaan Property dan Real Estate yang Terdaftar di BEI 2007-2011. Skripsi. Makassar: Program Sarjana. Universitas Hasanudin.

Almilia, Luciana Spica dan Emanuel Kristijadi. 2003. Analisis Ratio Keuangan untuk Memprediksi Kondisi Financial Distress Perusahaan Manufaktur yang Terdaftar di BEI Jakarta. JAAI, Vol.07, No.02, Desember 2003, pp. 1410-2420.

Andre, Orina. 2013. Pengaruh Profitabilitas, Likuiditas dan Leverage dalam Memprediksi Financial Distress. Skripsi. Padang: Program Sarjana. Universitas Negeri Padang.

Anggarini, Tifani Vota. 2010. Pengaruh Karakteristik Komite Audit terhadap Financial Distress. Skripsi. Semarang: Program Sarjana. Universitas Diponegoro.

Ararat, M., M. Aksu, dan A. T. Cetin. 2010. Impact of Board Diversity on Boards Monitoring Intensity and Firm Performance: Evidence from the Istambul Stock Exchange. Available at: http://ssrn.com/abstract=1572283. Diakses pada 20 Desember 2013.

Ariesta, Dwiki Ryno.2012. Analisis Pengaruh Struktur Dewan Komisaris, Struktur Kepemilikan Saham, dan Komite Audit terhadap Financial Distress. Skripsi. Semarang: Program Sarjana. Universitas Diponegoro.

Atmini, Sari dan Wuryana. 2005. Manfaat Laba dan Arus Kas untuk Memprediksi Kondisi Financial Distress pada Perusahaan Textille Products yang Terdaftar di BEJ. Seminar Nasional Akuntansi VIII. Universitas Brawijaya. Ayuningtyas. 2011. Analisis Pengaruh Struktur Kepemilikan, Board Composition, dan Agency Cost terhadap 
Distress Financial. Journal Ilmu Manajemen, Vol.01, No.01, Januari 2011.

Bapepam. 2000. Ketentuan Umum Pencatatan Efek Bersifat Ekuitas di Bursa. Kep.Direksi BEJ No.Kep-315/BEJ/062000.

2004. Pembentukan dan Pedoman Pelaksanaan Kerja Komite Audit. KEP-29/PM/2004.

. 2004. Pencatatan Saham dan Efek Bersifat Ekuitas selain Saham yang Diterbitkan oleh Perusahaan Tercatat. KEP-305/BEJ/07-2004.

Carter, D.A., Simkins, B.J., dan Simpson, W.G. 2003. Corporate Governance, Board Diversity, and Firm Value. Financial Review. Vol. 38 No. 1, pp. 33-53.

Darmadi, Salim. 2011. Board Diversity and Firm Performance : The Indonesian Evidance. MPRA Paper. No 38721, http://mpra.ub.uni-muenchen.de/38721. Diunduh pada 20 Desember 2013.

Elyanto, Alvin Agus. 2013. Analisis Pengaruh Karakteristik Komite Audit terhadap Financial Distress. Skripsi. Semarang: Program Sarjana. Universitas Diponegoro.

FCGI. 2001. Corporate Governance: Tata Kelola Perusahaan. Jilid I. Edisi ke-3. Jakarta: FCGI.

. 2002. Peranan Dewan Komisaris dan Komite Audit dalam Pelaksanaan Corporate Governance (Tata Kelola Perusahaan). Jilid II. Edisi ke-2. Jakarta: FCGI.

Ghozali, Imam. 2011. Aplikasi Analisis Multivatiate dengan Program IBM SPSS 19. Semarang: Badan Penerbit Universitas Diponegoro.

Hasymi, Mhd. 2007. Analisis Penyebab Kesulitan Keuangan (Financial Distress) Studi Kasus : Pada Perusahaan Dagang Konstruksi PT X. Tesis. Semarang: Magister Sains Akuntansi. Universitas Diponegoro.

Kalistarini, Dyah Swastika. 2010. Pengaruh Board Diversity pada Dewan Direksi dan Konsentrasi Kepemilikan Saham terhadap Firm Value dalam Perspektif Corporate Governance pada Perusahaan Indonesia. Skripsi. Solo: Program Sarjana. Universitas Sebelas Maret.

KNKG. 2006. Pedoman Umum Good Corporate Governance Indonesia. Jakarta: KNKG.

ristanti, Martinia Eny dan Muhammad Syafruddin. 2012. Pengaruh Karakteristik Komite Audit pada Kondisi Financial Distress. Diponegoro Journal of Accounting, Vol.01, No.02, pp. 1-15.

Kristanti, Martinia Eny. 2012. Pengaruh Karakteristik Komite Audit pada Kondisi Financial Distress. Skripsi. Semarang: Program Sarjana. Universitas Diponegoro.

Muthaher, Osmad. 2012. Metodologi Penelitian. Semarang: Unissula Press.

Nur Indriantoro dan Bambang Supomo. 1999. Metodologi Penelitian Bisnis untuk Akuntansi dan Manajemen. Yogyakarta: BPFE.

Nuresa, Ardina. 2013. Pengaruh Efektivitas Komite Audit terhadap Financial Distress. Skripsi. Semarang: Program Sarjana. Universitas Diponegoro.

Pembayun, Agatha Galuh dan Indira Januarti. 2012. Pengaruh Karakteristik Komite Audit terhadap Financial Distress. Diponegoro Journal of Accounting, Vol.01, No.01, pp. 1-15. . 2012. Pengaruh Karakteristik Komite Audit terhadap Financial Distress. Skripsi. Semarang: Program Sarjana. Universitas Diponegoro. 
Prasetyo, Eka Adhi. 2011. Faktor-Faktor yang Mempengaruhi Kondisi Financial Distress Perusahaan Perbankan yang Listing di BEI Tahun 2006-2008. Skripsi. Semarang: Program Sarjana. Universitas Diponegoro.

Purwanti, Atiek Sri. 2006. Pengaruh Karakteristik Komite Audit terhadap Ketepatan Waktu Pelaporan Keuangan pada Perusahaan Publik yang Terdaftar di BEJ. Tesis. Semarang: Program Pascasarjana. Universitas Diponegoro.

Rahmat, MM dan TM Iskandar. 2008. Audit Comitte Characteristics in Financially Distressed and Non Distressed Companies. Manajerial Auditing Journal, Vol.24, No.07, pp. 624-638.

Rustiarini, Ni Wayan. 2012. Komite Audit dan Kualitas Audit : Kajian Berdasarkan Karakteristik, Kompetensi, dan Aktivitas Komite Audit. Paper. Bali: Program Sarjana. Universitas Mahasariswati Denpasar.

Saniyah. 2009. Pengaruh Asimetri dan Pengungkapan Sukarela Terhadap Praktik Manajemen Laba Pada Perusahaan Manufaktur yang Terdaftar di BEl. Skripsi. Surabaya: Program Sarjana. Sekolah Tinggi IImu Ekonomi Perbanas.

Setiawan, Doddy dan Wahyu Widarjo. 2009. Pengaruh Rasio Keuangan Terhadap Kondisi Financial Distress Perusahaan Otomatif. Journal Bisnis dan Akuntansi, Vol.11, No.02, Agustus 2009, pp. 107-119.

Sihite, Rebecca Ciquita. 2012. Pengaruh Gender pada Dewan Komisaris, Dewan Direksi, dan Komite Audit terhadap Profitabilitas dan Kualitas Laba Perusahaan. Skripsi. Jakarta: Program Sarjana. Universitas Indonesia.

Veronicha, Suliana. 2012. Pengaruh Karakteristik Komite Audit terhadap Financial Distress pada Perusahaan Manufaktur yang Terdaftar di BEl. Skripsi. Semarang: Program Sarjana. Universitas Diponegoro.

Wardhani, RATNA. 2010. Karakteristik Pribadi Komite Audit dan Praktik Manajemen Laba. Seminar Nasional Akuntansi XIII.

Wulandari, Pitriya. 2011. Pengaruh Karakteristik Komite Audit terhadap Financial Distress. Skripsi. Solo: Program Sarjana. Universitas Sebelas Maret.

Yamin, Sofyan dan Heri Kurniawan. 2009. SPSS Complete : Teknik Analisis Statistik Terlengkap dengan Software SPSS. Jakarta: Salemba Infotek.

Jurnal Akuntansi Indonesia 


\section{LAMPIRAN}

Tabel 1

Definisi Operasional

\begin{tabular}{|c|c|c|c|}
\hline Variabel & Definisi Variabel & Lambang & Rumus \\
\hline $\begin{array}{l}\text { Ukuran Komite } \\
\text { Audit }\end{array}$ & $\begin{array}{l}\text { Jumlah anggota komite } \\
\text { audit }\end{array}$ & ACSIZE & Jumlah anggota komite audit. \\
\hline $\begin{array}{l}\text { Independensi } \\
\text { Komite Audit }\end{array}$ & $\begin{array}{l}\text { Proporsi anggota komite } \\
\text { audit yang independen }\end{array}$ & ACINDP & $\frac{\text { Komite Audit Independen }}{\text { Total Anggota Komite Audit }} x_{100 \%}$ \\
\hline $\begin{array}{l}\text { Pertemuan } \\
\text { Komite Audit }\end{array}$ & $\begin{array}{l}\text { Frekuensi pertemuan } \\
\text { rapat komite audit dalam } \\
1 \text { tahun }\end{array}$ & ACMEET & $\begin{array}{l}\text { Jumlah pertemuan rapat komite audit } \\
\text { dalam satu tahun. }\end{array}$ \\
\hline $\begin{array}{l}\text { Kompetensi } \\
\text { Komite Audit }\end{array}$ & $\begin{array}{l}\text { Proporsi anggota komite } \\
\text { audit berkompetensi }\end{array}$ & ACCOMP & $\frac{\text { Komite Audit Berkompetensi }}{\text { Total Ang gota komite Audit }} x 100 \%$ \\
\hline $\begin{array}{l}\text { Gender Wanita } \\
\text { Komite Audit }\end{array}$ & $\begin{array}{l}\text { Anggota komiter audit } \\
\text { bergender wanita }\end{array}$ & ACGEND & $\begin{array}{l}\text { Variabel Dummy } \\
1=\text { Ada Wanita } \\
0=\text { Tidak ada wanita (Laki-laki) }\end{array}$ \\
\hline $\begin{array}{l}\text { Kebangsaan } \\
\text { Komite Audit }\end{array}$ & $\begin{array}{l}\text { Anggota komiter audit } \\
\text { berkebangsaan asing }\end{array}$ & ACNAT & $\begin{array}{l}\text { Variabel Dummy, } \\
1=\text { Ada WNA } \\
0=\text { Tidak ada WNA (WNI) }\end{array}$ \\
\hline Reputasi KAP & $\begin{array}{l}\text { Rekutasi KAP yang } \\
\text { mengaudit perusahaan }\end{array}$ & REPKAP & $\begin{array}{l}\text { Variabel Dummy, } \\
1=\text { Big-4 } \\
0=\text { N-Big } 4\end{array}$ \\
\hline Sales Growth & $\begin{array}{l}\text { Pertumbuhan penjualan } \\
\text { perusahaan }\end{array}$ & SALGROW & $\frac{(\text { Penjualan Tahun Ini - Penjualan Tahun Lalu })}{\text { Penjualan Tahun Lalu }}$ \\
\hline Financial Distress & Kondisi Financial Distress & DISTRESS & $\begin{array}{l}\text { ICR }=\frac{\text { Laba Operasional }}{\text { Interest Expense }} \times 100 \% \\
\text { Variabel Dummy, } \\
1=\text { Jika ICR }<1 . \\
0=\text { Jika ICR }>=1 .\end{array}$ \\
\hline
\end{tabular}


Tabel 2

Distribusi Sampel

\begin{tabular}{|c|c|c|c|c|}
\hline \multirow{2}{*}{ Keterangan } & \multicolumn{3}{|c|}{ TAHUN } & \multirow{2}{*}{ Jumlah } \\
\hline & 2010 & 2011 & 2012 & \\
\hline $\begin{array}{l}\text { Perusahaan Sektor Jasa yang menerbitkan annual report dan financial } \\
\text { report }\end{array}$ & 223 & 223 & 223 & 669 \\
\hline $\begin{array}{l}\text { a. Perusahaan Sektor Jasa yang memiliki laporan komite audit tidak } \\
\text { lengkap. }\end{array}$ & (68) & (68) & (68) & (204) \\
\hline $\begin{array}{l}\text { b. Perusahaan Sektor Jasa yang memiliki financial report dalam mata } \\
\text { uang selain rupiah. }\end{array}$ & (17) & (17) & (17) & $(51)$ \\
\hline $\begin{array}{l}\text { c. Perusahaan Sektor yang memiliki nilai interst expense nol / } \\
\text { kosong. }\end{array}$ & (55) & $(32)$ & (37) & (124) \\
\hline $\begin{array}{l}\text { Perusahaan Sektor Jasa kategori Non Financial Distress sesuai kriteria } \\
\text { purposive sampling }\end{array}$ & 70 & 93 & 87 & 250 \\
\hline $\begin{array}{l}\text { Perusahaan Sektor Jasa kategori Financial Distress sesuai kriteria } \\
\text { purposive sampling }\end{array}$ & 13 & 13 & 14 & 40 \\
\hline $\begin{array}{l}\text { Perusahaan Sektor Jasa kategori Non Financial Distress yang terpilih } \\
\text { sebagai sampel }\end{array}$ & 13 & 13 & 14 & 40 \\
\hline $\begin{array}{l}\text { Perusahaan Sektor Jasa kategori Non Financial Distress yang terpilih } \\
\text { sebagai sampel }\end{array}$ & 13 & 13 & 14 & 40 \\
\hline JUMLAH SAMPEL & 26 & 26 & 28 & 80 \\
\hline
\end{tabular}

Tabel 3

Descriptive Statistics

\begin{tabular}{|c|c|c|c|c|c|c|c|c|c|c|c|c|}
\hline \multirow{2}{*}{ Ket } & \multicolumn{4}{|c|}{ Financially Distress } & \multicolumn{4}{|c|}{ Non Financially Distress } & \multicolumn{4}{|c|}{ All Sampel: } \\
\hline & Min & Max & Mean & $\begin{array}{l}\text { Std } \\
\text { Dev }\end{array}$ & Min & Max & Mean & $\begin{array}{l}\text { Std } \\
\text { Dev }\end{array}$ & Min & Max & Mean & $\begin{array}{l}\text { Std } \\
\text { Dev }\end{array}$ \\
\hline ACSIZE & 2 & 4 & 3.08 & .35 & 3 & 5 & 3.30 & .52 & 2 & 5 & 3.19 & .45 \\
\hline ACINDP & .67 & 1.00 & .90 & .15 & .67 & 1.00 & .96 & .11 & .67 & 1.00 & .93 & .13 \\
\hline ACMEET & 1 & 13 & 4.95 & 3.29 & 4 & 19 & 7.65 & 3.72 & 1 & 19 & 6.29 & 3.75 \\
\hline ACCOMP & .25 & 1.00 & .60 & .26 & .60 & 1.00 & .85 & .16 & .25 & 1.00 & .72 & .25 \\
\hline ACGEND & 0 & 1 & .12 & .34 & 0 & 1 & .55 & .50 & 0 & 1 & .34 & .48 \\
\hline ACNAT & 0 & 1 & .02 & .16 & 0 & 1 & .35 & .48 & 0 & 1 & .19 & .39 \\
\hline REPKAP & 0 & 1 & .30 & .46 & 0 & 1 & .82 & .39 & 0 & 1 & .56 & .50 \\
\hline SALGROW & -3.27 & 1.53 & .02 & .69 & -1.26 & 4.92 & .25 & .81 & -3.27 & 4.92 & .13 & .76 \\
\hline DISTRESS & - & - & - & - & - & - & - & - & 0 & 1 & .50 & .50 \\
\hline Valid N & & & & 40 & & & & 40 & & & & 80 \\
\hline
\end{tabular}


Tabel 4

\begin{tabular}{cccc}
\hline \multicolumn{4}{c}{ Hosmer and Lemeshow Test } \\
\hline Step & Chi-square & df & Sig. \\
\hline 1 & 1.026 & 8 & .998 \\
\hline
\end{tabular}

Tabel 5

\begin{tabular}{cccc}
\hline & \multicolumn{3}{c}{ Iteration History ${ }^{\mathrm{a}, \mathrm{b}, \mathrm{c}}$} \\
\hline Iteration & & -2 Log likelihood & Coefficients \\
\hline Step 0 & 1 & 110.904 & Constant \\
\hline
\end{tabular}

Tabel 6

Likelihood Overall Fit

\begin{tabular}{|c|c|c|}
\hline \multicolumn{2}{|c|}{ Iteration } & -2 Log likelihooc \\
\hline & 1 & 46.965 \\
\hline & 2 & 33.913 \\
\hline & 3 & 28.932 \\
\hline & 4 & 27.260 \\
\hline \multirow[t]{5}{*}{ Step 1} & 5 & 26.829 \\
\hline & 6 & 26.789 \\
\hline & 7 & 26.789 \\
\hline & 8 & 26.789 \\
\hline & 9 & 26.789 \\
\hline
\end{tabular}

Tabel 7

\begin{tabular}{cccc}
\hline \multicolumn{4}{c}{ Model Summary } \\
\hline Step & -2 Log likelihood & Cox \& Snell R Square & $\begin{array}{c}\text { Nagelkerke R } \\
\text { Square }\end{array}$ \\
\hline 1 & $26.789^{a}$ & .651 & .867 \\
\hline
\end{tabular}


Tabel 8

\begin{tabular}{|c|c|c|c|c|c|c|c|}
\hline & & B & S.E. & Wald & df & Sig. & $\operatorname{Exp}(B)$ \\
\hline \multirow{9}{*}{ Step $1^{\mathrm{a}}$} & ACSIZE & -1.058 & 1.975 & .287 & 1 & .592 & .347 \\
\hline & ACINDP & -12.627 & 5.268 & 5.745 & 1 & .017 & .000 \\
\hline & ACMEET & -.775 & .301 & 6.613 & 1 & .010 & .461 \\
\hline & ACCOMP & -3.162 & 3.086 & 1.049 & 1 & .306 & .042 \\
\hline & ACGEND & -4.866 & 2.101 & 5.362 & 1 & .021 & .008 \\
\hline & ACNAT & -7.321 & 2.727 & 7.209 & 1 & .007 & .001 \\
\hline & REPKAP & -3.078 & 1.490 & 4.265 & 1 & .039 & .046 \\
\hline & SALGROW & -2.488 & 2.056 & 1.465 & 1 & .226 & .083 \\
\hline & Constant & 27.548 & 10.339 & 7.100 & 1 & .008 & 9.204E11 \\
\hline
\end{tabular}

Tabel 9

\begin{tabular}{ccccc}
\hline \multicolumn{5}{c}{ Omnibus Tests of Model Coefficients } \\
\hline & & Chi-square & df & Sig. \\
\hline Step 1 & Step & 84.114 & 8 & .000 \\
\hline & Block & 84.114 & 8 & .000 \\
\hline & Model & 84.114 & 8 & .000 \\
\hline
\end{tabular}

Gambar 1

Kerangka Teoritis

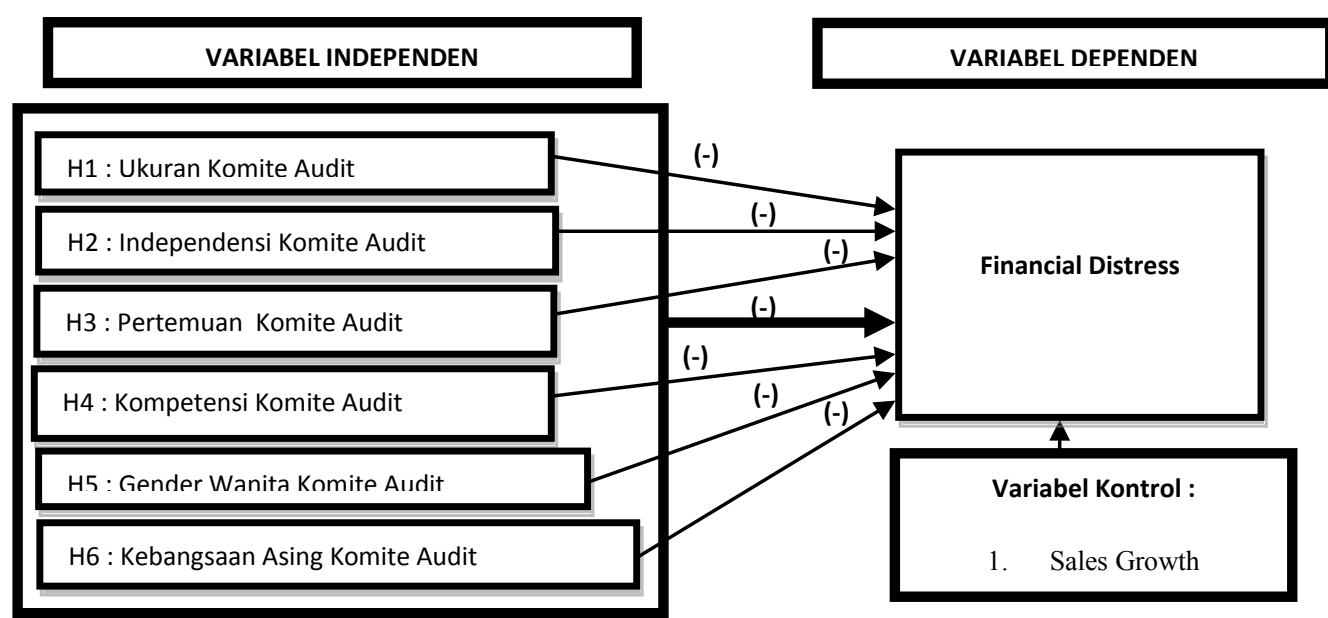

